\title{
Avoin julkaiseminen ja vastuullinen tiede
}

\author{
Susanna Nykyri \\ Tampereen teknillisen yliopiston kirjasto \\ susanna.nykyri@tut.fi \\ https://orcid.org/0000-0002-5018-5176
}

Asiasanat: open access; vastuullisuus; tieteellinen julkaisutoiminta; toimitustyö

Avoin julkaiseminen on paljon muutakin, kuin että itse julkaisut ovat avoimesti kaikkien luettavissa. Siihen liittyvät myös mm. toimintatapojen ja julkaisujen taustalla olevien tutkimusdatojen ja menetelmien avoimuus. Osana avoimuuden kehittämistä Informaatiotutkimuksen yhdistys (ITY ry) on yhteistyössä Kulttuurintutkimuksen seuran kanssa laatimassa avointa vertaisarviointia koskevaa selvitystä, joka valmistuu tulevana syksynä. (Hankkeesta, ks. Jytilä, Koikkalainen, Laakso, \& Nykyri, 2018) Lehdessä odotetaan kiinnostuneena tuloksia, jotka toimivat tukena myös meidän tuleville ratkaisuille.

Osa tehdyistä ratkaisuista vakiintuu, osa jää kokeiluksi. Viime numerossa ilmeni, että kirjoitusten XML/HTML-versioissa on puutteita etenkin viitteissä johtuen taustalla olevan OJS-lisäosan bugeista. Takaiskuista huolimatta emme ole luopumassa XML/HTML-versioista, mutta joudumme korjauksia odotellessamme varoittamaan lukijoita näiden versioiden käytöstä. - Koemme tähdelliseksi, että jatkossakin meillä tarjotaan kummatkin versiot (PDF+XML/HTML) ja että osallistumme XML/HTML-version kehittämistyöhön, vaikka sen ratkaisujen testaajana toimiminen on välillä olettamaammekin vaativampaa.

Olen ikävän tietoinen siitä, että pääkirjoituksessani taas toistan itseäni. Silti koen tarpeelliseksi muistuttaa, että Suomessa avoin tiedelehtijulkaiseminen on edelleen vailla toimivaa rahoituspohjaa - huolimatta Kotilava-hankkeen ponnisteluista. Informaatiotutkimus-lehdessäkin painimme edelleen rahoitusongelman kanssa, ja kaikki sen ratkaisemiseksi nähty vaiva on luonnollisesti poissa itse tiedetoimittamiselta.

Artikkeli on lisensoitu Creative Commons Nimeä-EiKaupallinen-JaaSamoin 4.o Kansainvälinen -lisenssillä

Pysyvä osoite: https://doi.org/10.23978/inf.73196 
Niin Informaatiotutkimus-lehti kuin sen taustalla oleva Informaatiotutkimuksen yhdistys (ITY ry) tarvitsevat toimintansa tueksi jäsen- ja kannatusmaksuja. Haluankin jälleen kiittää jäsen- ja kannatusmaksunsa suorittaneita yksittäisiä jäseniämme ja alamme oppiaineita siitä, että tieteenalallamme on kaikille avoimesti luettavissa oleva informaatioalan tiedelehti ja että myös seminaaritoimintamme on avointa.

Luopumistakin tapahtuu. Painettua vuosikirjaa emme enää toimita, vaan jatkossa panostamme yksinomaan verkkojulkaisuun. Julkaistujen aineistojen määrä on viime vuosien aikana reilu kolminkertaistunut, mikä kertoo ennen kaikkea lehden elinvoimaisuudesta. Se on kuitenkin samalla tiennyt myös mittavaa taittourakkaa ja kohonneita painatuskustannuksia. Vuosikirjan hinnalla ei voida kyllin kattaa em. kuluja. Asiaan vaikutti suuresti myös se, että lehteen tarjottavien käsikirjoitusten ja lukijoiden määrän kasvusta huolimatta vuosikirjan levikki on pysynyt pienenä.

Tiedetoimittaminen vaatii asiantuntijuutta ja aikaa. Siitä tulisi voida saada sellainen korvaus, joka mahdollistaa sälllisen ajankäytön. Riittävä aikaresurssi on omiaan myös parantamaan laatua ja vähentämään kiireestä ja väsymyksestä johtuvia huolimattomuusvirheitä. Lehden toimihenkilöille suunnattavien korvausten merkitys onkin siinä, että ne mahdollistavat ajan ostamisen toimitustyölle.

Avoimuus on ollut Informaatiotutkimus-lehdelle jo pitkään selkeä arvo, jota toteutetaan myös käytännössä. Avoin julkaiseminen mahdollistaa kaikille pääsyn tietoon ja on lisäksi omiaan parantamaan tieteen laatua. Avoimuuteen ja laatuun liittyy nykyään enenevissä määrin myös tiedejulkaisun taustalla olevan tutkimusdatan avoimuuden tavoite. Silloinkin, kun julkaisun tulosten taustalla olevaa dataa ei voi perustelluista syistä avata, tulisi keskeinen metadata olla silti avointa. Tämä on nykyään myös esimerkiksi Suomen Akatemian vaatimus.

Lehdessämme avoin data on toistaiseksi vielä suositus, mutta vahva sellainen. Taustalla on käytännön ymmärrys siitä, että avaamisen edellytyksenä oleva kyllin huolellinen datanhallinta ja datan seikkaperäinen dokumentaatio (metadata) eivät ole vielä toivotulla lailla vakiintuneita käytäntöjä. Datanhallinnan ja metadatan merkitys ovat kuitenkin saaneet viime aikoina paljon ansaitsemaansa huomiota, ja käytäntöjä ja palveluita niiden ympärille kehitetään aktiivisesti niin kansallisella kuin kansainvälisellä tasolla.

Myös tiedelehtiä ja -seuroja koskee tutkimustoiminnan eettinen arviointi. Siihen liittyen allekirjoittanut on laatimassa yhteistyössä DORAn kanssa suomennosta DORA-julistuksesta (DORA (2012), ks. DORAsta myös Varantola (2014)). Suomennos on tarkoitus julkaista Informaatiotutkimus-lehden Avoin tiede ja avoin tieto -teemanumerossa (4/2018) ja myös DORAn sivuilla. ITY allekirjoitti julistuksen 29.5.2018. DORAn kansallista merkitystä on lisännyt mer- 
kittävästi se, että Suomen yliopistojen rehtorineuvosto UNIFIn Avoimen tieteen ja datan toimenpideohjelmassa (UNIFI, 2018) on mukana sitoutuminen DORAjulistukseen ja avoimuuden tunnustaminen tutkijanuraa edistäväksi ansioksi.

Eettisyyteen sisältyy myös mm. vastuullisesti huolehdittu käsikirjoitusten arviointi. Se, että vain vertaisarvioitujen tiedeartikkeleiden (julkaisutyypit A1/A2) yhteydessä on Tieteellisten seurain valtuuskunnan (TSV) myöntämä vertaisarviointitunnus, ei suinkaan tarkoita sitä, että lehden muita kirjoitustyyppejä ei arvioitaisi. Katsausartikkelit (B1) ja kirja-arvioinnit (B1) myös arvioidaan ja niistä annetaan tarvittaessa niiden sisältöä ja/tai kirjoitusasua koskevaa palautetta. Em. palautteen taustalla on kuitenkin usein toimituskunta, jonka kesken tätä työtä jaetaan. Kirjoituksen aiheen niin vaatiessa tukeudumme tässäkin arviointi- ja kommentointityössä luonnollisesti myös ulkopuolisiin arvioijiin.

Julkaisutyyppien moninaisuus on tärkeä osa koko tiedeviestintää ja julkaisemista. Toivonkin, että meille tarjotaan myös katsauksia, kirja-arvioita ja lektioita ahkerasti jatkossakin ja että kirjoittajansa muistavat raportoida ne myös taustaorganisaatioidensa tutkimustietojärjestelmiin.

Käsikirjoituksia tarjoavia muistutan, että lehden kirjoittajaohjeisiin tulee aina tutustua huolella. Toimituskunta arvioi taas loppukesästä ohjeistusten päivitystarpeen ja otamme mielellämme palautetta ja kehitysideoita ohjeiden ja kuvausten sisällöstä ja muotoiluista! - Palautetta voi antaa allekirjoittaneelle (snykyri [at] gmail.com / susanna.nykyri [at] tut.fi), toimituskuntamme jäsenille tai vaikka ITY:n Facebook-sivujen ${ }^{1}$ kautta.

Nyt käsillä olevan numeron toimitustyöstä on jälleen erityiskiittäminen toimitussihteeriämme FM Matti Lassilaa. Hän jää pois toimituskuntamme vahvuudesta muiden kiireiden vuoksi ensi vuodenvaihteessa. Sujuvan siirtymän helpottamiseksi loppuvuoden numeroiden toimitustyössä on mukana tuleva toimitussihteerimme, informaatioalan ja viestinnän asiantuntija FM Harri Ollikainen. Tervetuloa vahvuuteen!

Kaunis kiitos käsikirjoituksia tarjonneet ja koko toimituskunta! Kiitos jälleen myös käsikirjoituksia arvioinneille ja kommentoinneille tärkeästä työstänne!

Nötössä 25.6.2018

Susanna Nykyri

1 ITY:n Facebook-sivut löytyvät osoitteesta: https://www.facebook.com/ informaatiotutkimus/ 


\section{Viitteet}

DORA. (2012). San Fransisco Declaration on Research Assesment. DORA Community. https: //sfdora.org/read/

Jytilä, R., Koikkalainen, R., Laakso, R. and, \& Nykyri, S. (2018). Avointa vertaisarviointia koskevalle selvitykselle rahoitus. Informaatiotutkimus, 37(1). https://doi.org/10.23978/inf.70172

UNIFI. (2018). Avoin tiede ja data. Toimenpideohjelma suomalaiselle tiedeyhteisölle. 28.5.2018, Suomen yliopistokirjastojen rehtorineuvosto UNIFI ry. http://urn.fi/URN:NBN:fife2018052424593

Varantola, K. (2014). Kenen integriteetti, kenen vastuu? Acatiimi, (2/14). Keskustelua. http://www. acatiimi.fi/2_2014/02_14_14.php 